\title{
Street Vending as Strategy for Livelihood of Urban Poor: in Addis Ababa, Ethiopia
}

\author{
Brhanu Tsegay Mesele \\ Department of Sociology, Wolaita Sodo University, Ethiopia
}

\begin{abstract}
This study aimed at assessing the nature of street trade, existing conditions of the street traders at their work settings, exploring the threats and risks faced by them, driving forces of street trade, and analysing livelihood outcomes of street trade both on the operators and the poor urban dwellers in Addis Ababa, Ethiopia. Due to the nature of the study, Qualitative research method was used. Purposive sampling under non-probability sampling method was employed. Primary data was collected from street traders and some customers of in the purposively s elected streets. Two streets (Megenagna and Mexico) were purposively selected for which the researcher had observed that street trade is rampant and there are many street traders operating in these areas. Among the driving forces why people engage in street vending as to some people is that they got it better to supplement the income they get from the other livelihood strategies (income earned from formal employment, but there are also others engaged due to chronic poverty. Some venders become engaged in street trade activities because it does not demand much start-up capital intermes of finance and skill but better option to earn income and accumulate capital and maximize profit. Street traders are found vulnerable to different hazardous conditions due to their activities. As reported by the informants, the street trade activity in urban informal sector is found to be pivotal for the livelihood enhancement of the street traders and other sections of poor dwellers. According to urban authorities, street vending activity in is directly associated with illegality, criminality, poor sanitation of the urban environment, and congestion of pedestrians on the behalf of the urban authorities.
\end{abstract}

Key terms: Street trade, driving forces, livelihoods, economic importance

DOI: 10.7176/RHSS/9-5-02

Publication date:March $31^{\text {st }} 2019$

\section{Introduction}

In its simplest terms, street vending falls within the category of economic activities generally referred to as the informal sector. Despite the existence of substantial literature about the informal sector, there is still no concise and universally agreed definition of this sector. Studies indicate that there are at least as many ways of defining the informal sector as there are countries where it has been studied (Tinker, 1997; Cross, 1998). Notwithstanding this diversity, in general terms, the informal sector can be defined as ,legal and ethical sound"e economic and commercial activities that take place outside government's licensing and regulatory framework such that only the entrepreneurs themselves regulate their activities. Being one of the highly visible informal sector activities, street vending is basically "unregulated" trading that takes place in public spaces such as streets, sidewalks, bridges, and pavements (Joseph, 2011).

Street trade is rampant and a source of employment and income for many urban dwellers. Street vending has a significant contribution in the urban and national economy of African countries. However, in most of the 
countries, it is unaccounted and unrecognised in national economic statistics. Street trade has in the past, been viewed as an underground activity that undermines the healthy function of the formal economy. This perception has resulted in conflicts with urban authorities over licensing, taxation, site of operation, sanitation and working conditions (Amsale, 2017:34).

Considering the evolving nature and complexity of street vending, studies conducted on the issue have been minimal. Nevertheless, there are considerable numbers of studies conducted in different areas across time. Some studies tried to examine the reasons why people engage in street vending while others to see the contribution of street vending to the national economy. Besides, there also other studies that focused on the growth of street vending, types of street vending activities and social networks of street vendors.

A study conducted by (Manganga cited in Tamirat and Nega, 2015), depicts that street vending which is the main and visible part of the informal sector is a global phenomenon. Millions of people earn their living by selling goods and services on the sidewalks in the majority of developing countries urban centres. They represent a significant share of the urban informal sector.

According to the findings of Manganga (2007), street vending is a shield which buffers many people in it, who are not formally employed and also disadvantageous in many aspects. Whether legitimate or not, street venders practice their trade under in hospitable conditions. Since, street vending is directly related to the urban spaces or illegal access to public places, eviction orders are issued arbitrarily in the causing of congestions, health reasons, and public inconvenience over the street vendors (Kumar and Singh cited in Tamrat and Nega 2015:2).

Unemployment, low productivity in agriculture and the need to migrate to the urban to search for employment has forced millions of the youth in developing countries to engage in informal trade (Aryeetey cited in Mramba, 2015). Globally, it was estimated that in 2000s, the informal sector constituted $18 \%$ of economy in OECD countries, $38 \%$ of the economy in transition countries and $41 \%$ in developing countries. In fact, the informal sector contributes about 55 per cent of Sub-Saharan Africa's GDP and 80 per cent of the labour force (African Development Bank, 2014).

As to Cross (1998), although it has been argued that street vending preferred mainly by those who have limited opportunities for obtaining formal employment, there are also conditions in which those who have the opportunity of obtaining formal employment engaged in street vending activities in many cities and towns.

According to Mitullah, generally, there has been little research done on the informal sector activities in Africa (cited in Tamrat and Nega, 2015). There studies conducted on street vending were inadequate and information available is largely deficient and locality specific in Africa. Likewise, the situation is also similar in the case of Ethiopia. In spite of that, in majority of African countries including Ethiopia there has been growing recognition that this sector is becoming the major employer, (Asmamaw cited in Tamrat and Nega, 2015).

Now days, the condition of life making through the informal sector activities including being engaged in street vending in Ethiopian major cities and towns is becoming a common phenomenon. Almost all of the main roads of the main cities and towns in the country are overcrowded with street venders selling various goods and services to consumers.

Ethiopia like, many other sub-Saharan African countries has been experiencing rapid population growth and high rates of migration into the cities and large towns. In cities and towns, most of these people find it difficult to get jobs in the formal economic sectors due to their limited education and lack of skills for formal employment. In 
their quest for making a living, many of these people have limited choices other than taking to the streets by engaging into street vending activities. Addis Ababa being the country's capital city is accommodating a substantial share of these phenomena. This is mainly due to its too large composition of urban poor and migrant population coming from different parts of the country. Large numbers of street venders operate on the road side and round bouts of Addis Ababa. Since the city is too large and hosting intensive street vending activities almost in all its corners, primarily, attention was drawn to Megenagna and Mexico streets and round-bouts where there are many street venders operating in the area. Hence, the researcher wanted to investigate the existing conditions of street venders in detail, the nature of street vending, how it is serving as a livelihood strategy for the venders, driving forces of street vending, challenges that venders are facing, government policy and regulation measures towards street vending.

\section{Literature Review}

\subsection{Growth of the Informal Sector and Street Vending}

There is a substantial increase in the number of street vendors in the major cities around the world, especially in the developing countries of Asia, Latin America and Africa. The explanation can be found in the following factors:

Firstly, lack of gainful employment coupled with poverty in rural areas has pushed people out of their villages in search of a better existence in the cities. These migrants do not possess the skills or the education to enable them to find better paid, secure employment in the formal sector and they have to settle for work in the informal sector. Secondly, there is another section of the population in these countries who are forced to join the informal sector. These are workers who were employed in the formal sector. They lost their jobs because of closures, down-sizing or mergers in the industries they worked in and they or their family members had to seek low paid work in the informal sector in order to survive (Amit ; Rajul, 2015:15).

Available statistics show that street vending accounts for 15 to $25 \%$ of total informal employment in Africa's cities and contributes between 46 to $70 \%$ of total trade value added in Benin, Burkina Faso, Chad, Kenya, Mali, and Tunisia, (Skinner 2008). In Zimbabwe, street vendors represent one third of the population and 100000 of these are said to be in Harare, (Njaya, 2016). However, there has been a general tendency to reduce the activities of street vendors as a nuisance within the urban milieu.

Despite the street vendors ${ }^{\text {ee }}$ role in the economy, Dube and Chirisa (2012) observed that street vendors continue to struggle at the margins of the economy. The failure to recognise street vendors as entrepreneurs with potential to generate income has resulted in loss of potential revenue from street vending registration fees, hawking licenses and taxes since the street peddlers continue to operate without licenses (Uzhenyu, 2015).

\subsection{Theories of Informal Sector}

There are three schools of thoughts about the informal sector. These are: romantic, parasite, and dual.

\subsubsection{Romantic View}

The romantic view De Sato, holds that, most of the informal undertakings are not quite different from the formal one; the distinction is that, they happen to be born in informal environment. If they will be intervened by the government in terms of policies, regulations, capital and skills they could perform in the same way as the formal 
sector (Granström, 2009). Basing to this view the informal sector is an engine of growth just waiting to be released by giving informal firm's property rights (Porta \& Shleifer cited in Mramba 2015). According to this view informal firms are potentially productive, but held back by government policies, regulations, and limited access to finance. Therefore if such barriers would be eliminated informal businesses would register and take advantage of the benefits of their formal status. Generally, this view believes that informal undertakings are basically similar to official ones.

\subsubsection{The Parasite view}

The Parasite view sees informal enterprises from the perspectives of illegality and presents them as a means to gain an unfair advantage in their competition with the formal sector (Mramba, 2015). It views, informal sectors as surviving at the expense of the formal sector. The parasite view holds that informal firms need to stay small to avoid detection. The decision to remain in the informal economy is a rational one, because the cost advantage of escaping taxes and regulations allows unofficial firms to undercut official firms in prices. Informal firms are thus hurting growth because their small scale makes them unproductive and because they take away market share from more productive, formal competitors. Government policy should aim to eradicate informal firms by reducing tax evasion and increasing government regulation enforcement.

\subsubsection{Dualistic View}

According to the dual view as advocated by Harris and Todaro informal firms are highly inefficient, do not pose much threat to the formal firms, but also do not contribute to economic growth, which is driven by the efficient formal firms (Porta \& Shleifer, cited in Nasibu and Mramba 2015:3). The dualists argue that the informal actors and their operations have few linkages to the formal economy, but, rather, operate as a distinct separate sector of the economy (Chen, 2007). Given the heterogeneity of the informal economy, there is some truth to each of these perspectives. Unlike the previous study (La Porta \& Shleifer, 2014), this work is in favour of De Soto's romantic view of informality. This means that if the street vendors will be empowered in terms of business permits, policy, regulation special vending zones, appropriate business skills, and business security they would provide impetus to income growth and general business development which in turn could reduce poverty.

\subsection{Making Street Vending Business Work for Income Poverty Reduction}

Adenutsi (2009) argues that entrepreneurship e.g. Street vending business is the catalyst for economic growth and development through job creation, income, empowerment and poverty reduction in an economy. This suggests that in order to create high-income generating job opportunities and reduce poverty through entrepreneurship, there is the need for policy measures and intervention programmes that are critical and consistent with the objective of welfare improvements. In this sense there is a need for government and other development stakeholders to intervene the operation of street vending business in order to make it work for poverty reduction.

According to (Wadzanai cited in Mramba, 2015:3) who carried a study in Zimbabwe, the informal cross border trade contributes positively to poverty reduction. The contribution has been noticed through the improvement in the socioeconomic well-being of traders, traders to acquire assets, and improved food security. Another study by (Misati, 2010) in Kenya argues that the creation of wealth and poverty reduction in sub-Sahara Africa is associated with informal sector particularly through the creation of employment. The study recommends that, policy in low income countries should include the role of informal sectors and the governments should 
improve the working conditions of the informal sector.

Yeboah's (1980) study in sub-Saharan Africa argues that instead of discouraging informal trade activities emphasis should be on encouraging them and providing them with institutional, managerial, technical, and financial support necessary to grow and contribute to the economies. All these studies prove the ability of the informal sector to contribute to poverty reduction, through creation of employment and earnings. However, all the studies recommend to the government to develop favourable policy and regulation for smooth and effective informal sector operation (Mitullah, 2010).

In many developing countries street vending is often looked down as an undesirable activity undertaken by criminals which impinges on the use of public space. Also, it is often persecuted, lives in uncertainty, and works in poor conditions, with little access to infrastructure (Donovan, 2008). Being a part of the marginalized urban poor, street vendors are treated as trouble makers whose sole purpose is to create chaos on the streets (Bhomick, 2005). The public criticizes the existence of street vendors because they cause congestions and jams on the road; however the www.ccsenet.org/ibr International Business Research Vol. 8, No. 5; 2015124 formal business owners do not like street vendors because they cause unfair competition because of the low priced goods.

\subsection{The Importance of Street Trade}

Street trade is rampant and a source of employment and income for many urban dwellers. (Charmes cited in Mitullah, 2003) in his work provides some figures that can be used for assessing the importance of vending activities. In 1999, street based workers in Kenya were estimated to number 416,294. This accounted for 5.2 per cent of the non-agricultural labour force of which women were 3.9 per cent cited in (Mramba, 2015:3). This situation shows that street vending have a significant contribution in the urban and national economy of African countries.

Although it has been argued that vending attracts those who have limited opportunities for obtaining formal employment and/or prestigious business, and minimises chances of social exclusion and marginalisation; street vending is increasingly becoming an option for many citizens. It is no longer limited to the lower social groups, A number of entrepreneurs have entered the trade as an option, especially since the beginning of the Structural Adjustment Programmes [SAPs] that resulted in the retrenchment of civil servants across Africa (Winnie V. 2003).

\section{Economic and social importance of street vending to the state economy}

According to Fletcher and Ahmed (2011), street vending activities play three fundamental roles in the economic systems of cities. The first essential role of street vending is that it is an important form of employment to a substantial number of the urban and migrant population. Street vending also indirectly sustains jobs of other employees who work in industries which manufacture or produce the wares sold by the street vendors (Chen, 2007). As such it is not only the livelihood of vendors which relies on street vending but also the farmer, small scale producers and other home-based industries who lack the resources to market their own product.

The second important economic contribution of street vending according to Flaming et al. (2015) is that the activities of street vendors have a cascading effect across the local economy. This is shown when street vendors sell their products to passers-by, as their profits accumulate; it leads to higher demand for more goods and services from local suppliers. Demands from suppliers in this chain enable the more employment opportunities in the 
upstream supplier chain thereby broadening the tax revenue base for the state.

Street trade is an important part of the economy, because it employs a large number of less educated people and acts as a "shock absorb" in the livelihood and earnings of the poor (Lyons \& Msoka, 2008a). Furthermore many women vendors are major breadwinners in poor households in developing countries (Mitullah, 2003; Kusakabe, 2006). In a context of economic growth it is virtually the only redistributive mechanism for spreading the benefits of growth to large numbers of the poor.

(Flaming et al, 2015; Ray and Mishra, 2011) stated that street vendors offer a low-cost, decentralised and highly efficient system of distributing products required on a daily basis. These are goods such as fruits and vegetables, a market which the formal sector cannot adequately serve. The Food and Agriculture Organisation (FAO) has also acknowledged the important role played by street vendors in promoting access to food at low prices, (FAO 2016).

\subsection{Street Trade Regulations and Policy}

Street vending is mainly affected by policy and practice of both national and local governments. Majority of street vendors around the world, undertake street vending business with the threat of eviction, jail, harassment, and fines because street vending activities are usually not recognized or protected under legal and regulatory frameworks. Almost in all countries in Africa, they operate with restrictive policies and regulations that lay emphasis on the illegality of street vending (Bhowmik, 2005; Mitullah, 2003). As informal activities (street vending activities) in many countries are on the fringes of the law, authorities often confuse them with criminal activities and subject them to oppression (ILO cited in Brown, 2006). According to Brown (2006: 191), actions of local governments can be a major hindrance to the development of a secure environment for street trading.

Different case studies revealed that most Local Authorities are operating without dated bylaws that require review. Most cities have placed the responsibility for street trading in wrong departments, with most of them managing street traders through the Traffic and Enforcement Departments. In this respect, vendors are viewed as a problem that has to be controlled rather than to production units that contribute to the urban economy. Although South Africa is still a young country, it has initiated processes through its Constitution, that have potential for improving the business environment for micro and small scale enterprises, providing services to communities and promoting social and economic development. For the street vending business to work towards poverty reduction there is a need for the African governments to formulate supportive policies, regulations and organization of street vending space that will provide legal protection while conducting business.

With regard to awareness of by-laws vending applicable to their operations in most street vendors are not aware of these by-laws case except in Kenya and Uganda. Findings show that many street vendors are unaware of the existence of by-laws, and have no access to them while others know but choose to ignore them.

\section{Research Methods}

Addis Ababa, capital of the country (Ethiopia) in which informal sector activities especially street vending activity is undertaken in wide rage. This study was confined to Addis Ababa, Megenagana and Mexico streets and round bouts due to the researcher's familiarity to the area and had closely observed situations of street vending in the 
areas mentioned. Besides, it is impossible to cover all street vending activities across all streets of the city due to various reasons. Purposive sampling under non-probability sampling method was employed. Street venders who sell different goods and services were the subjects of this study. Primary data was collected from street venders in the purposively s elected streets. .Qualitative research method was used. The reason why this method was used is that due to the nature of the study demanding in-depth and richer information to understand and examine the nature, conditions of street vending, threats, risks and challenges that venders are facing, driving forces for employing street vending activities as a livelihood strategy, importance of street vending and policy and regulation measures the government has towards street vending. In order to achieve this, qualitative method found best suited to this study. In addition to this, finding out the policy and regulation issues regarding street vending could not be addressed unless qualitative method was employed.

\section{Methods of data collection}

Qualitative data was collected from purposively selected street vendors, the urban authorities, some clients of street venders, regarding the working condition, importance of street vending both for the venders and consumers, and policy issues and regulation mechanisms related to street vending. In-depth interview, key informant interview, focus group discussions and observation was used as qualitative data collection tools. Accordingly, 12 in-depth interviews were conducted with street venders. Key informant interview was also conducted with 4 urban authorities both at Sub-city and woreda level. This was done with officers working in the micro and small scale enterprises and trade and industry department in Lideta and Bole sub-cities and two respective woredas. Other four peoples who are clients of street vendors were selected accidently and interviewed. Besides, four focus group discussions were also conducted in the study area. FGD were organized considering participant's age, sex, and educational status. Thus, the FGDs were conducted with men and women youngsters, and adult women. Check lists and guidelines was prepared to collect the qualitative data using the respective data collection instruments. Furthermore, information was gathered through personal but non- participant observation of the researcher on the situation of street vendors in the study area.

Finally, Data gathered through different data collection tools were organized to keep data quality and analysed thematically.

\section{Study Results}

This part deals with data presentation and analysis of the data collected by using the different qualitative data collection tools such as, in-depth interview, key informant interview, focus group discussion and observation.

\subsection{Socio- demographic characteristics of street vendors}

Educational status of street vendors: low educational level characterizes most street traders which is caused by low socio-economic status of families. Especially the youth street vendors are mostly school dropouts from primary and secondary education. However, there are some vendors who are still striving to continue their education. Since majority of the vendors quitted their education and spent much of their time on vending, street vendors lack adequate education and training to get formal employment.

Age structure: In terms of age category, street vending activities are dominated by the migrant youths, adults 
and some adult people (both women and men). Though youths are dominating groups among others, there is also significant amount of adult people engaged in vending various things such as, selling, food stuffs like tea, coffee, bread, biscuits, and other goods. This is finding is in line with the finding of (Tamrat, 2012). Most of the migrant youths came from the country side while most of the adult women are urban poor dwellers in Addis Ababa. The street vendors are come from different parts of the country having different ethnic and religious backgrounds.

\subsection{Types of items Vended on the Streets}

Street trade in its nature is heterogeneous, comprising a wide variety of activities. Street traders vends a range of commodities which includes foods products/stuffs (fast food, bread, tea, coffee, tomatoes, onions, potatoes, cabbage, bananas, orange,...), new/second hand clothes, shoes, electrical appliances, equipments used for beautification, different household goods, and stationary materials, cigarettes, sweets, belts, umbrellas, soaps, and watches etc. They also vend books, mobile cards, CDs, USBs, mobile safety glasses, posters, and plastic products.

Most case studies conducted in many African countries show that women dominates street vending activities in various African cities and towns. Unlikely, this study found out those men especially the young men dominates vending activities in Addis Ababa. However, there is also significant number of women engaged in vending activities in the study area where this study is conducted.

Regarding the nature of products sold by gender, women generally sell items which need low capital input such as cooked and non-cooked food stuff, jewellery, and cosmetics whereas men are vending cloths and shoes, books, CDs and DVDs, hardware electrical appliances, umbrellas, watches, and socks in most cases. The working condition of street vendors varies. Some vendors place themselves at strategic points where there is heavy human traffic.

Usually, women are working in a permanent place rather than men. Men move from one corner of the city to another depending on the time and location of streets where there are heavy human trafficking. However this does not mean that women do not move. There some youth women move from one corner to another and trade various products. The average hours of work for vendors varies from four to thirteen hours a day. The vendors have mostly been found to be working for prolonged durations in unsympathetic surroundings which adversely affect their health.

\subsection{Nature and Working Conditions of Street Vending}

There continues to be debate as to whether informal self-employment is a survival tactic or an entrepreneurial strategy. Urbanisation, migration and economic development have led to an increase in the number of street vendors in African cities. Studies suggest that these street vendors tend to take up street vending as a last resort to obtain a living. In some Asian countries the share of informal employment rose from 53 percent in 1980-89 to 63 percent in the period 1990-99. According to a 2006 estimate of the International Labour Organisation (ILO) over the next 10 years, 500 million people would join the world's job markets, most of them young people in developing countries with secondary level education and training. They will join 180 million unemployed and the 550 million working poor (ILO cited in Amit. and Rajul , 2015:12). 


\subsection{Forces for Choosing Street Vending as of Urban Poor's Livelihood Strategy}

Substantial studies conducted on migration explain that the informal sector is a source of employment and livelihoods for rural-urban migrants. In fact, the causes behind street trade are varied. According to the claims of the 'dualist' school of thought, the poor begin street businesses as they cannot find jobs in the formal economy (Amsale, 2017:21). Street vending, therefore, serves as another option for them where low barriers to entry make it likely to earn income and make a living. In most cases, these groups of people are associated with high vulnerability contexts to low productivity, food insecurity and poverty and, hence, are forced to join the informal sector in general and street trade in particular.

In contrast to the dualist model, the 'voluntarist' school of thought asserts that people join street vending because it provides a more flexible and attractive employment choice than salaried work (Fransen and Van Dijk, 2008). This proposition is proved by some empirical studies. For example, (Yamada,; Douglas et al. cited in Getaneh, 2015:102) argued that the informal sector is a better opportunity sector and that informal workers join it to exit bureaucracies and regulations of the formal sector.

In this study, the data collected concerning the reasons for participating in street trade show that there cases in which reasons why people engage in street vending activities fit the propositions of both the dualist and voluntarist schools of thought. In other words, some joined street trade because of lack of other means of livelihood opportunities while others entered into street activities voluntarily either to supplement their meagre income from other sources or because the street businesses are profitable. This finding is consistent with Perry's (2007), finding who came up with; all activities in the informal sector are not survival strategies. Instead, people may voluntarily join informality to escape government rules and evade regulatory burdens and taxes. Discussions results with key informant interviewees show that people join informality due to different reasons. Asked about the driving forces to be engaged in the informal sector/street vending, a woman interviewee, and 46 years old, engaged in selling foods stuff like tea, bread, and coffee alongside has said the following:

I am working as a janitor in one of the government institutions. I have got divorced with my husband five years ago and taking caring of our three children rests on me. My salary which is less than ETB 700.00 is not sufficient to fulfil our basic needs. To support our livelihood, I started the street business of selling food stuff. I do street business on part-time basis. I have been working almost eleven hours during the weekends. During the working days, I work after office hours. I have started to get good amount of money from the street business and now I am able to feed my children three times a day and able to pay for school fees. The income from the street business is better than my salary. Now, I am thinking of quitting my job and expanding the street business. 
Some others as well join street vending as it relatively provides better income than other activities that they used to work before. In this case, a male interviewee 24 years old who sells belts and watches said:

It is me who is supporting the family living outside Addis Ababa. I am a school dropout. I have been in the street business of selling belts, watches and bags for the last 4 years. Before joining this business, I have been engaged in farming and support my parents. But the agricultural produces I got from this activity was not sufficient to feed my family. Then, I joined the street business and now I am able to support my parents. Street vending is not only my business but also a means of livelihood.

Similarly, a male interviewee, 22 years old, who sells electric appliances, said:

I am from a family of many children. Our family consisted of seven members. We were depending on agriculture for our livelihoods. My life of migration started after my family became unable keep us attending school. Due to this, I decided to come to Addis Ababa in search of employment opportunities. After my arrival, I started to look for jobs but failed to get one. In fact, I have got a job as a daily labourer in the construction sector but could earn enough income to fulfil my needs and support my parents. The only option that I had was to start street business. With some help from my friends, I began to sell hardware electric appliances on streets. Now, I am able to support myself and support my family keep my brothers attending school I also send money to my parents during holidays and whenever they are in need. Besides I am learning to have driver licence.

Likewise, a male interviewee, 45 years old, who sell closes said the following: I have been selling cakes and Breads in a mini shop. I started to sell clothes on streets now because I was unable to pay house rent and make profit while I was selling in my shop. People rarely come to my shop because the prices were relatively expensive due to expensive house rent. Street venders were tough to compete for they were selling cheap because they do not have extra rent expenses and do not pay taxes. On the streets, however, I am able to sell much and able to make profit.

From the above interview transcript and analysed results of this study shows that failure to secure employment in formal establishments, the need to support family, and dissatisfaction with previous employment conditions were among the major factors that pushed people into street vending business. Hence, based on the above cases, it is possible to understand as there are different reasons that forced/push people to choose street vending as livelihood strategy for different people.

\subsection{Threats, Risks and Hardships Faced by Street Vendors}

Considering the nature of street trade vendors are vulnerable to a number of health hazards. Venders often work in environments that expose them to hazards such as accidents and illnesses. This is due to the unhygienic surroundings, lack of sanitation facilities, and exposure to pollution, excess contact with sun and rain etc. the finding of this study regarding the hardships that venders faced is in line with other studies which were conducted in different countries like India, and Kenya. Venders often trade along pathways of congested traffic and concentrated air pollutants exacerbate conditions such as asthma, allergies, tuberculosis and chronic bronchitis (Gamieldien and Niekerk, 2017). 
In these areas, the traders are at risk of tightness of the chest, sore throats, colds and coughs. For some venders, physical injury may be caused by prolonged participation in excessively strenuous physical activities such as loading and offloading their goods on a daily basis. Results of this study regarding vender's health and well-being is found consistent with a study in Dar Es Salaam (Gamieldien and Niekerk, 2017), indicated that traders are exposed to biological, ergonomic, physical and psychosocial hazards.

In addition, street traders are continuously on the run due to constant harassment, assault and seizure of goods by the local government authorities or police in and other users of the city space. Street vendors face a number of difficulties outside of their control. This includes conflict with police, customers and fellow traders, competition for similar goods, negative public attitudes and daily physical obstructions. Usually, street traders are usually concerned with confrontation with local authorities, and at the end they lose their products and money (Mramba, 2015). The vendors respond to this situation by resorting to corruption, while many enforcement officers openly ask for bribes.

Furthermore, although street trade does not require much start-up capital like the formal one, they are challenged by limited access to capital, unstable security, and harassment from the owners of formal business, and low level of business skills. They lack intrinsic empowerment, basic freedoms, and self-confidence, walking with dignity, feeling secured, and living without fear. These hindrances limit opportunities for street vending business to work efficiently for the income poverty reduction

\subsection{Economic importance of street trade to vendors, urban poor dwellers and national economy}

The importance of this sector has been underestimated, neglected, and usually seen more as a liability rather than a potential resource of employment creation and a source of income for many people. This negligence of the street vending activities has resulted in the lack of accurate estimates of the numbers of street traders in many African countries. However, there are indicators that show the growing importance of street vending for many people. Findings of many case studies conducted on the issue of street vending shows that street vending has a significant contribution in the urban and national economy of African countries. Although it has been argued that vending attracts those who have limited opportunities for obtaining formal employment and/or prestigious business, and minimizes chances of social exclusion and marginalisation; street trade is increasingly becoming an option for many citizens. It is no longer limited to the lower social groups. A number of entrepreneurs have entered the trade as an option.

For instance, the Uganda case study shows the importance of the informal economy throughout Uganda's turbulent civil strife. The informal sector is nearly the largest employer in Uganda accounting for 13 per cent of the labour force as compared to 5.3 per cent in the formal sector. Likewise, the importance of the informal economy in general and street vending in particular is significantly growing in the Ethiopian cities and towns despite the lack in accurate estimate about to what extent this informal sector is contributing to the national economy (Mitullah, 2003).

Street trade is an attractive economic strategy and source of livelihood for the unskilled and illiterate new arrivals to the city. Due to the increase in rural-urban migration and the contracting formal sector, street vending and other forms of informal employment become the most attractive means of survival for the inbound immigrants and urban poor as well. In general, vending has become an important source of employment for a large number of 
urban poor.

Street trade is playing an important role by becoming a coping mechanism for low income households in the city of Addis Ababa since it provide low-cost basic goods and food items to other lower income groups. According to Roever (2014), evidence shows that the monthly incomes from street trade are very low compared to the national average of formally employed individuals. On the contrary, in the study area where this study is conducted, most street vendors engage in street vending activities to supplement their low income which is consistent with Mengistu and Jibat's research finding which was conducted in 2012.

The users of the advantage of street trade are not only the street venders, but also the majority of the urban poor dwellers who buy much of their daily needs and wants to them. Life for such section of society can be hard without street venders. The urban poor cannot tolerate the increasing inflation in price of goods and services and afford the price of goods and services in the informal sector. Thus, engaging in street vending activities is affordable and convenient livelihood strategy for this group of people. Furthermore, Street vending activities contribute to the livelihoods of millions of people and to national wellbeing at large because it serves as an emerging largest employer sector countries like Ethiopia.

Although many of the street traders are not aware of the by-laws applicable to their operations, almost all of the venders and some of the public who are clients do not acknowledge their eviction and confiscation by the local authorities. It threats the survival issue of both the street venders and other poor urban dwellers that depend on them for fulfilment of majority of their needs and wants.

Street trade is not temporary; it is an alternative to job creation and as a strategy for livelihood of the urban poor. Despite, urban authorities still consider street vending activity as an illegal and unproductive activity

\subsection{Policy Measures to Regulate Street Trade}

Policies or laws are tools for setting standards in the provision of public goods and services in order to protect consumers, investors and the general public, while by-laws set controls that ensure that urban areas are safe and clean. In most cases, local authorities in Africa are seen as a major obstacle to the development of informal sector activities like street vending in urban areas. Most of them use out-dated restrictive policies, by-laws and regulations originally intended to control and regulate the growth of indigenous enterprises, which does not require much capital to invest (Mitullah, 2003: 9-10).

According to the officers working in the woreda trade and industry department, the restrictions make vending principally illegal, and view vendors as responsible for making cities dirty, obstructing traffic, affecting the normal functioning of the formal sector and therefore a public nuisance. On the contrary, vendor study participants of this study claimed that the laws are harsh and discouraging self-employment, and denying the youth from making living. Otherwise, such kinds of restrictive policies almost absolutely forgotten or deny that these street vendors add considerable comfort to the lives of thousands by selling essential items at convenient locations and relatively fair price. The fact that these street vendors aren't taxpaying contributors to the economy adds ire of the authorities against them and they end up giving illegal payments to municipal and police officers. This results due to lack of or no inclusive urban planning in this regard. Hence, they demand a policy that appreciates street vending as a vital livelihood strategy for the urban poor.

Different case studies revealed that most Local Authorities are operating without dated bylaws that require 
review. Most cities have placed the responsibility for street trading in wrong departments, with most of them managing street traders through the Traffic and Enforcement Departments. In this respect, vendors are viewed as a problem that has to be controlled rather than to production units that contribute to the urban economy. Unlike most African countries, South Africa has initiated processes through its Constitution, that have potential for improving the business environment for micro and small scale enterprises, providing services to communities and promoting social and economic development (Mitullah, 2003) .

In fact, there is an attempt to encourage micro and small scale enterprises both in rural and urban areas by the Ethiopian Government. The government tries to legalize some street venders and allow them to vend in some selected public spaces. This is done when if vendors fulfil some preconditions. However, considering the nature and growth of street trade and the role it is playing in accommodating large number of people in urban areas, the government's trial is not adequate. The policy measure used to regulate street trade in urban areas so far does not recognise the ever growing vending activities in urban centres and associated functions to the urban poor dwellers and the state as well. This needs revise policy measures towards street vending in urban areas (Mitullah, 2003).

Additionally, in most case except for Kenya and Uganda, street vendors are not aware of the by-laws applicable to their operations. Findings show that many street vendors are unaware of the existence of by-laws, and have no access to them while others know but choose to ignore them (Mitullah, 2003:11). This is also absolutely true in Ethiopian case. There are some venders who are aware of the by-laws applicable or not to their operations while others are unaware with regard to the by-laws. This is made worse by the lack of effective street vendors associations to expose vendors to policies and regulations and to lobby for the review of policies, by-laws and integration of vending activities in urban development programs. Conventionally, this is can be treated as a major obstacle to the growth of street vending activities in Africa.

\section{Discussion Results}

The contribution of street trade as an empowering occupation was felt to be relevant in which a large proportion of the population face severe resource constraints and formal employment opportunities. As to discussion results from the focus group discussions, factors that trigger individuals to be engaged on street trade can be categorized as push and pull factors.

\section{Push factors}

According to the discussion participants in this study, the main reason people in urban areas take up street trade is because of Low socio-economic background, limited employment opportunities, and deficiencies in agricultural productivity, food insecurity, and poverty. Thus, street trade has become an important source of employment for a large number of urban poor. Street trade provided a coping mechanism in times of economic hardships.

\section{Pull factors}

Unlike push factors which force individuals/ members of a household to engage in street trade necessarily, pull factors are factors that attract individuals to be engaged on street trade activities. Even though push factors highly influence individuals employ street trade as a strategy for livelihood, there are also some other factors regarded as pull factors that motivated people to be engaged on street trade 
Some of the study participants in the FGDs and in-depth interview noted that the positive changes they witnessed on individuals/ households who have been involved street trade activities attracted them to do so. Individuals/ households who had been engaged on street trade activities build some fixed assets such as, built a house with collated iron, bought some oxen, and other cattle using the income they generated from such activities. This in turn, motivated other individuals to be engaged on street trade. In addition to this, some young members of a given household who have been engaged on some street trade activities share their friends about the opportunities that are available with regard to engagement on street trade activities. Here, the social networks of youngsters play a significant role in motivating them to be engaged on street activities.

Besides, some discussion participants of this study noted that they decided to be a street trader because street trade does not require much more financial capital and skill but enable to earn better income than other activities that they used to work before

\section{Conclusion and Recommendations}

\subsection{Conclusion}

This study was conducted with the major objective of investigating the nature, working conditions of street trade, driving forces to engage in street trade activity, threats, risks, and challenges that venders are facing, street trade as strategy for livelihood of urban poverty and urban poor dwellers and policy measures devised to regulate street trade in Addis Ababa. Qualitative methodologies were used to examine the objectives set out before the actual study

Some of them include in-depth interviews, key-informant interviews, focus group discussion with street venders in which each were guided by interview guide and check lists and observation. The data collected using the qualitative data collection tools were analysed thematically.

Street vending has become the most important livelihood option to large amount of rural-urban migrants and poor urban dwellers in Addis Ababa. There are many street traders in almost every corner of the city in general major streets and round -bouts like Megenagna and Mexico in particular. Street vending in its nature is heterogeneous, comprising a wide variety of activities. Street traders vend a range of commodities. and have mostly been found to be working for prolonged durations in unsympathetic surroundings which adversely affect their health.

There are various factors that force/initiate people to be engaged on street trade in urban areas. Low socioeconomic background, Limited employment opportunities in the formal sector due to low educational status, and skill, deficiencies in agricultural productivity, food insecurity, and poverty are some of the factors regarded as push factors that force individuals to engage on street trade activity in the study area.

Besides, emerging opportunities in the informal sector in general and street trade in particular initiate others to consider street trade as alternative strategy for their livelihoods. People involved in street trade either to diversify their sources of income in addition to the primary income they got from the formal sector or engaged in street trade business because it does not require much start-up capital but serve as a better means to capital accumulation and maximize profit easily.

The street vending activity in urban informal sector is found to be pivotal for the livelihood enhancement of 
the street venders and other sections of poor dwellers. The majority of the urban poor dwellers buy much of their daily needs and wants with relatively fair and affordable price. Furthermore, Street vending activities serves as an emerging largest employer sector countries like Ethiopia.

Nonetheless, Street venders are found to be vulnerable to different hazardous conditions due to the nature of their activities, illegality and urban authorities' response towards street vending activities in Addis Ababa is like in many of the developing countries' larger cities. According to the study participants, street vending is directly associated with illegality, criminality, poor sanitation of the urban environment, and congestion of pedestrians on the behalf of the urban authorities. Besides, the government consider street vending as it affects the normal functions of the formal sector. Thus, needs to be controlled.

\subsection{Recommendations}

The growth of the informal sector in general and street vending activity in particular is growing in an alarming rate. Considering the growth rate of the informal sector, the government needs to devise an inclusive urban development plans and programs that explicitly recognize street vendors as works for the role they play in generating economic activity, providing jobs, and brining retail goods to the poor urban consumers with relatively fair price. The measure taken to legalize street traders should be advanced considering the growth of the informal sector in major cities and towns of the country. 


\section{References}

1. Adenutsi, D. E. (2009). Entrepreneurship, job creation, income empowerment and poverty reduction in lowincome economies. A Seminar Paper Presented at the Inaugural/1st Induction Programme of the Chartered Institute of Economists, (pp. 1-21). Accra Ghana.

2. African Development Bank. (2014). Recognizing Africa's Informal Sector.

3. Amit C. and Rajul J (2015:15). Property Rights of Street Vendors. Centre for Civil Society (ccs@ccs.in)

4. Amsale A. (2017). Street vending and Local Authorities in Addis Ababa city: Challenges and the way forward, Addis Ababa.

5. Brown, A. (2006). Contested Space: Street Trading, Public Space and Livelihoods in developing Cities. Rugby, England : ITDG Publishing .

6. Chen, M. (2007). Rethinking the informal economy: Linkages with the formal economy and the formal regulatory environment. United Nations University, World Institute for Development Economics Research.

7. Cross, J. C. (1998), Informal politics: Street vendors and the state in Mexico City. Stanford University Press, California.

8. De Soto, H. (1989). The other path: The informal revolution. New York.

9. Donovan, M. G. (2008). Informal cities and the contestation of public space: The case of Bogotáes street vendors. Urban Studies, 45(1), 29-51.

10. Dube, D,Chirisa, I (2012). The Informal City: Assessing its Scope, Variants and Direction in Harare, Zimbabwe. Vol1(1).

11. FAO, FAO conducts survey on Street Food Vendors in Accra .2016

12. Flaming, D., Burns, P. \& Liu, Y. Y. (2015). Sidewalk Stimulus. Economic and Geographic Impact of Los Angeles Street Vendors. California: East LA Community Corporation.

13. Fransen, J., and M. P. van Dijk. (2008). Informality in Addis Ababa, Ethiopia.

14. Gamieldien F. and, Niekerk L. (2017). Street vending in South Africa: An entrepreneurial occupation, South African Journal of Occupational Therapy, 2017; 47(1): 24-29

15. Getahun F. (2015). Social Capital and the Urban Informal Economy: The Case of Street Vendors in Addis Ababa, Ethiopia, University of Trento.

16. Granström, C. S. (2009). The informal sector and formal sector competitiveness in senegal. Nationalekonomiska Institutionen, Department

17. Kusakabe, K. (2006). Policy issues on street vending: An overview of studies in Thailand, Cambodia and Mongolia. International Labour Office.

18. Manganga K(2007). Street vending in post- operation murambatsvina Harare. The kumba, Cameroon. Department of Geography, university of Buea, Cameroon. Living on the migrants Conference, Stellenbosch 26-28 March 2003.

19. Misati, R. N. (2010). The role of the informal sector in investment in Sub-Saharan Africa. International Entrepreneurship and Management Journal.

20. Mitullah, W.V. (2003). Street Vending in African Cities: Synthesis of Empirical Findings from Kenya, Cote d'Ivoire, Ghana, Zimbabwe, Uganda and South Africa, Washington

21. Molefe Coper Joseph (2011). The struggle to belong Dealing with diversity in 21st century urban settings, 7- 
9 July 2011 Amsterdam.

22. Nasibu R. Mramba (2015). The Conception of Street Vending Business (SVB) in Income Poverty Reduction in Tanzania, College of Business Education (CBE), Mwanza, Tanzania.

23. Njaya, T, (2016). An evaluation of income disparities between male and female street vendors of Harare in Zimbabwe. Vol. 2(3)

24. Ray, C. N. and Mishra, A., Vendors and Informal Sector: A Case-Study of Street Vendors of Surat City. Centre for Urban Equity CEPT University: Ahmedabad, India. 2011

25. Roever, S. (2014), Street trade in Latin America: Demographic Trends, Legal Issues, and vending Organizations in six cities, Dept. of public Administration Leiden University, Netherlands

26. Skinner, C. (2008). Street trade in Africa: A review. Kwazulu-Natal: School of Development Studies, University of Kwazulu-Natal.

27. Tamirat M. (2012). Street vending as the safety -net in Addis Ababa: The case of Arada sub-city.

28. Tamrat M and Nega J.(2015). Street vending as safety-net for the disadvantaged people: the case of Jimma Town, Jimma University, Ethiopia. Journal of Sociology and Anthropology

29. Tinker, I. (1997) Street foods: Urban food and employment in developing countries. Oxford University Press, Oxford.

30. Uzhenyu, D, Formalisation of the Informal Sector in Zimbabwe, A Key Success Factor to Sustainable Development. 2015

31. Yeboah, I. E. (1998). What's informal about the informal sector? Culture and the construction of development in sub-Saharan Africa. East African Geographical Review, 